\title{
O estudo das formas comunicativas como disciplinas do corpo: o caso da fotografia huichol
}

Sarah Corona Berkin

Universidad de Guadalajara, Mexico

E-mail:saco99@prodigy.net.mx

O que me motivou a ir para Sierra Madre Ocidental à procura de jovens indígenas que, ao contrário dos povos do extremo Ocidente, não tivessem a experiência cotidiana com a imagem fotográfica, televisiva ou cinematográfica, foi o desejo de explicar o impacto das videoculturas aliado a um sonho nômade adolescente. Inicialmente pretendia dar continuidade a meu trabalho com crianças receptoras, procurando conhecer hábitos e preferências do seu consumo de meios de comunicação, assim como identificar e observar práticas que se apropriassem dos conteúdos desses meios de comunicação e de seus contextos.

O terreno escarpado da Serra Huichola, as dificuldades para seu acesso, o contato com o outro, muito outro, satisfez plenamente meu sonho pendente; quanto à explicação do impacto dos meios de comunicação massiva, a pesquisa original sofreu alguns tropeços. O trabalho que ora apresento ${ }^{1}$ é o resultado de tudo isso.

Os duzentos quilômetros de Guadalajara a San Miguel Huaixtita, Estado de Jalisco, exigem uma viagem de madrugada, de caminhão, a Ixtlán do Rio, Nayarit, para se chegar antes das seis da manhã, a tempo de pesar as bagagens e embarcar em pequenos aviões. São fatos importantes se considerarmos que esses pequenos aviões têm de cinco a nove lugares e que os passageiros vão carregados de mantimentos e outras mercadorias necessárias ao trabalho na serra. Os huicholes aproveitam a viagem à cidade para fazer compras, já que dispõem de poucos produtos em casa e de que esta é uma maneira de poupar, escapando dos altos preços cobrados pelos comerciantes da serra. Até mesmo as visitas carregam mochilas, bolsas e caixas com comida suficiente para a estadia, uma vez que, mesmo sendo convidados, os costumes de San Miguel os obrigam à retribuição da hospitalidade.

O pequeno avião decola ao clarear do dia e as ordens de vôo são distribuídas de acordo com a quantidade de passageiros, os destinos solicitados e, parece-me, as preferências étnicas e os interesses da empresa. Mestiços serranos

1. ALAIC, Chile, 2000 - Versão preliminar. 
e huicholes, assim como antropólogos, agentes de movimentos sociais ou funcionários de órgãos governamentais esperam seu turno. Na maioria das vezes, o vôo para San Miguel sai depois do meio-dia. Mas pode também ser adiado por vinte e quatro horas, por muitas razões, inclusive o mau tempo, o que torna imprevisível a chegada à serra.

\section{OS HUICHOLES}

O difícil acesso é o primeiro obstáculo para o contato dos nativos com as imagens ocidentais, uma vez que só muito esporadicamente chegam jornais, revistas ou livros. O fato de não haver sistema elétrico impede, também, o funcionamento de tecnologias de comunicação mais sofisticadas. Somente o rádio é usado, uma vez que se conhecem os receptores à pilha.

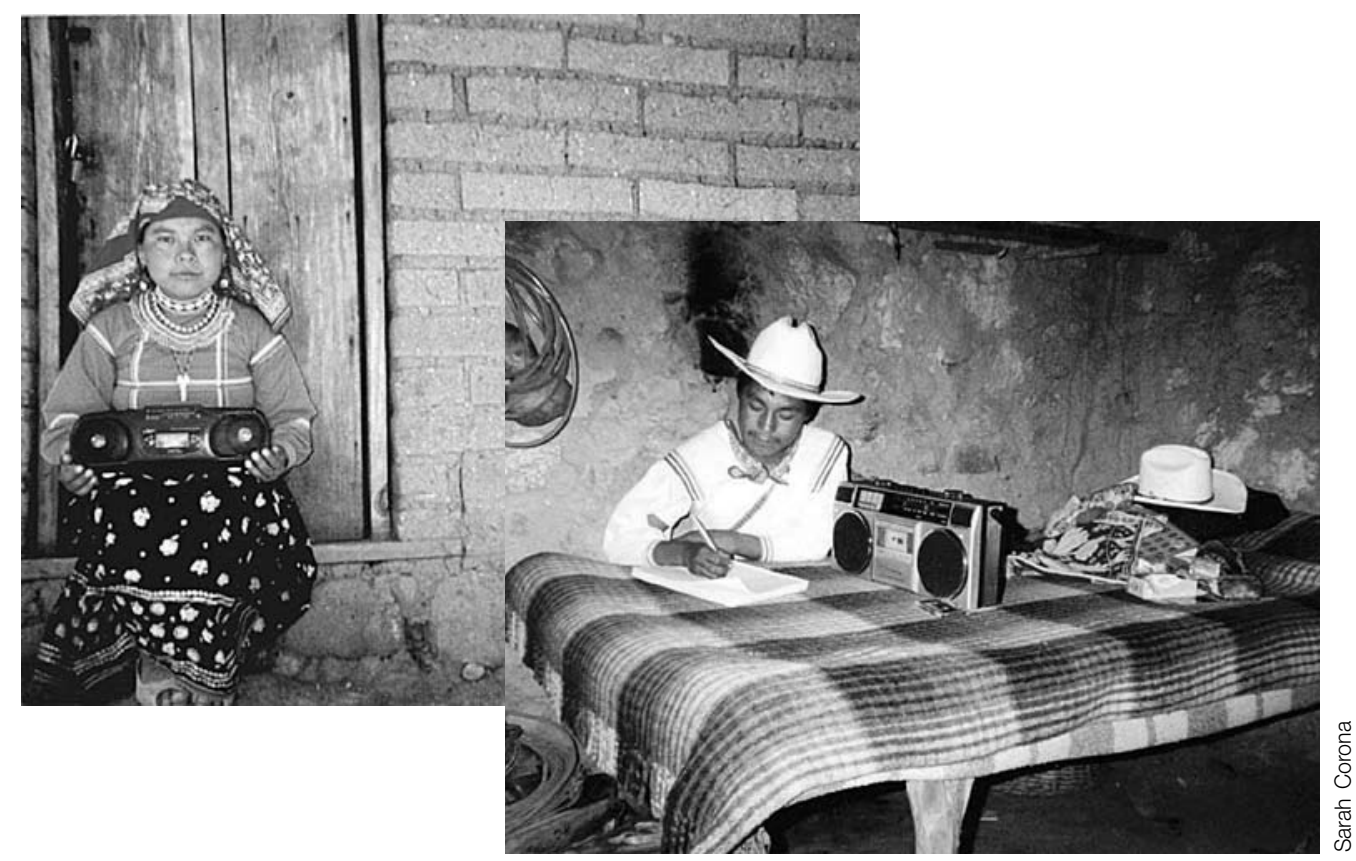

Os huicholes são sujeitos predominantemente emissores,

e não receptores de meios massivos de comunicação, nem apropriadores de imagens, motivando o estudo de suas formas de expressão e seus significados.

Por outro lado, os huicholes são um dos 54 grupos indígenas do México que conservam sua própria língua. Apenas $50 \%$ dos huicholes, ou wixarika, como são chamados em seu idioma, são bilíngües e falam espanhol com certa dificuldade. Eles também constituem um dos grupos indígenas com maior porcentagem de monolingüismo. As crianças são, aliás, reservadas, e as que vivem nas ladeiras das montanhas, as quais apenas principiam a aprender o espanhol nos cursos de alfabetização, falam pouco até mesmo com os seus companheiros.

Ao contrário dos demais grupos mexicanos, entre os quais $91 \%$ são cristãos, só $48 \%$ dos huicholes declaram sê-lo. Obedecem a autoridades tradicionais e 
praticam rituais próprios. Muitas zonas do seu território carecem de estradas, eletricidade e, portanto, de produtos de consumo ocidentais e de meios massivos de comunicação. Essas características no seu conjunto podem ajudar a explicar a permanência de seus costumes e tradições, bem como a importância que outorgam à conservação de sua identidade étnica.

Assim, tendo de estudar sujeitos predominantemente emissores, e não receptores de meios massivos de comunicação, nem apropriadores de imagens, foi necessário reorientar nossa pesquisa, desviando-nos de nosso interesse inicial em relação ao consumo dos meios de comunicação e de seus produtos para nos voltarmos às formas de expressão dos huicholes e seus significados. Os sujeitos de minha pesquisa transformaram meu objeto de estudo e minha metodologia, dando lugar a outros enfoques. Procurei afastar-me de uma perspectiva centrada na imagem, que tem a ver com o mundo da escrita e das videoculturas, optando por aproximar-me da complexa inter-relação de formas de comunicação presentes em uma comunidade indígena, especialmente a oral.

\section{COMUNICAÇÃO E CULTURA}

A partir das pesquisas realizadas na América Latina na última década, por Jesús Martín Barbero, Leôncio Barrios, Nestor García Canclini, Guillermo Orozco, Martha Renero e Maria Immacolata Vassallo de Lopes, neste campo pouco sistemático da comunicação social, sabemos hoje que os meios eletrônicos propõem formas de comunicação que são apropriadas pelos receptores, segundo sua idade, gênero e ambiente sociocultural. Isso nos leva a analisar não só as formas de apropriação dos meios, como também as produções comunicativas dos diferentes sujeitos produtores de discursos. Estudá-los através da análise dos discursos exige entender as formas específicas de ação das linguagens sociais.

Por isso, atualmente, dedico-me ao estudo das práticas comunicativas de jovens indígenas huicholes por meio de suas formas de expressão orais, escritas e de imagens.

Com base em uma etnologia da comunicação, assim como de uma reflexão semiótica de análise da imagem, da oralidade e da escrita, pesquisam-se cartas de amor redigidas pelos jovens huicholes, canções tradicionais e modernas compostas por autores locais, peças de teatro e 2.700 fotos tiradas por esses mesmos sujeitos. Em outras palavras, parto do que o sujeito escreve, canta, fala e fotografa para conhecer as competências que o orientam.

Essas produções não resultam apenas de um talento individual no manejo das linguagens, mas também de uma série de disposições que se traduzem em saberes e competências coletivas. Assim, podemos reconhecer nos discursos dos huicholes uma visão a-icônica, no seu sentido mediático, em oposição ao olhar ocidental, disciplinado pela imagem. Esclarecemos, todavia, que, procurando evitar confusão entre os muitos conceitos de imagem - literária, simbólica, sonora, tátil -, entendo por imagem e iconicismo, como Eco, "A relação semântica entre um signo gráfico como veículo e um significado perceptivo codificado"2.
2. ECO, Umberto. La estructura ausente. Introducción a la semiótica (A estrutura ausente. Introdução à Semiótica). Barcelona: Lúmen, 1975. p. 229. 
A esta ordem pertencem as fotografias, o cinema, a televisão, os cartazes, a pintura, o desenho e a ilustração impressa.

Os novos espaços privados e públicos invadidos pela imagem têm configurado uma época na qual a principal forma de comunicação é a-icônica, constituindo o que Giovanni Sartori, Regis Debray e Paul Virilio chamam de videosfera, videocultura ou industrialização da visão. Acreditamos que os trabalhos de McLuhan, criticados por sua descontextualização histórica e política e suas conclusões apressadas, devem ser retomados à luz de disciplinas como Etnologia, Sociologia e Semiologia para que se entendam, além das especificidades dos meios de comunicação, as formas como eles se relacionam com os contextos, promovendo diferentes competências e práticas comunicativas. Nesse sentido, falar da cultura huichol é falar da cultura oral permeada por certos elementos visuais e de escrita.

Como será o olhar em uma comunidade sem imagens mediáticas? Qual é seu código da expressão escrita amorosa e qual sua relação com outras formas de comunicação? O que olham e como o fazem estes indivíduos através de uma lente fotográfica? Que relação existe entre o olhar a-icônico e o universo que rodeia o huichol? Por oposição, como se modifica o olhar do sujeito das videoculturas e o discurso amoroso na modernidade? Estas são só algumas das perguntas que surgem ante a produção discursiva dos jovens huicholes.

Vou agora expor certas conclusões advindas do estudo da linguagem fotográfica nesta pesquisa. As fotografias foram analisadas por uma metodologia que combinava análise temática, semiológica e discursiva, permitindo encontrarmos os temas e as funções das fotos, os elementos que as estruturam, o manejo do espaço, do corpo humano e dos objetos, aliados a uma explicação contextual a qual compreende a fotografia como forma de produção de significação na comunidade de jovens huicholes. A informação reunida por esses diferentes dispositivos, junto à observação levada a cabo durante minhas estadas na comunidade, permitiu uma interpretação das fotos e a identificação de um código fotográfico particular.

\section{AS FOTOGRAFIAS E SUA ANÁLISE}

Dediquei-me a recolher e analisar as fotografias como lugar de interseção do olhar individual e coletivo dos huicholes. Seria ingênuo de minha parte pensar que as fotografias são expressões puras do mundo huichol, uma vez que toda representação é convencional, resultante de múltiplas interações que envolvem a tecnologia fotográfica, a voz do fotógrafo e a presença do destinatário.

A experiência foi realizada na escola secundária, onde cem câmeras simples, com capacidade para 27 fotos cada, foram distribuídas entre cem alunos e professores. Solicitou-se que usassem as máquinas para tirar 20 fotos a partir de um tema, enquanto as sete restantes deveriam ser tiradas livremente. Foram dadas explicações básicas do uso do equipamento, evitando-se erros primários, como a obstrução da lente pela mão, a contraluz e danos à máquina provocados por poeira e água. 
Os cem alunos e mestres fotografaram sua comunidade durante uma semana, perfazendo um total de 2.700 fotografias que foram reveladas e devolvidas aos alunos. Depois, a partir de um conjunto de fotos selecionadas, foram feitas entrevistas individuais em que se pôde classificar o material e resolver dúvidas relativas às fotos.

A interpretação das imagens fotográficas, neste ponto da pesquisa, baseou-se em trabalhos antropológicos precedentes desenvolvidos para estudo da arte indígena e formas de expressão corporal da cultura huichol. Essa interpretação foi depois contraposta às próprias interpretações dos huicholes para as mesmas imagens.

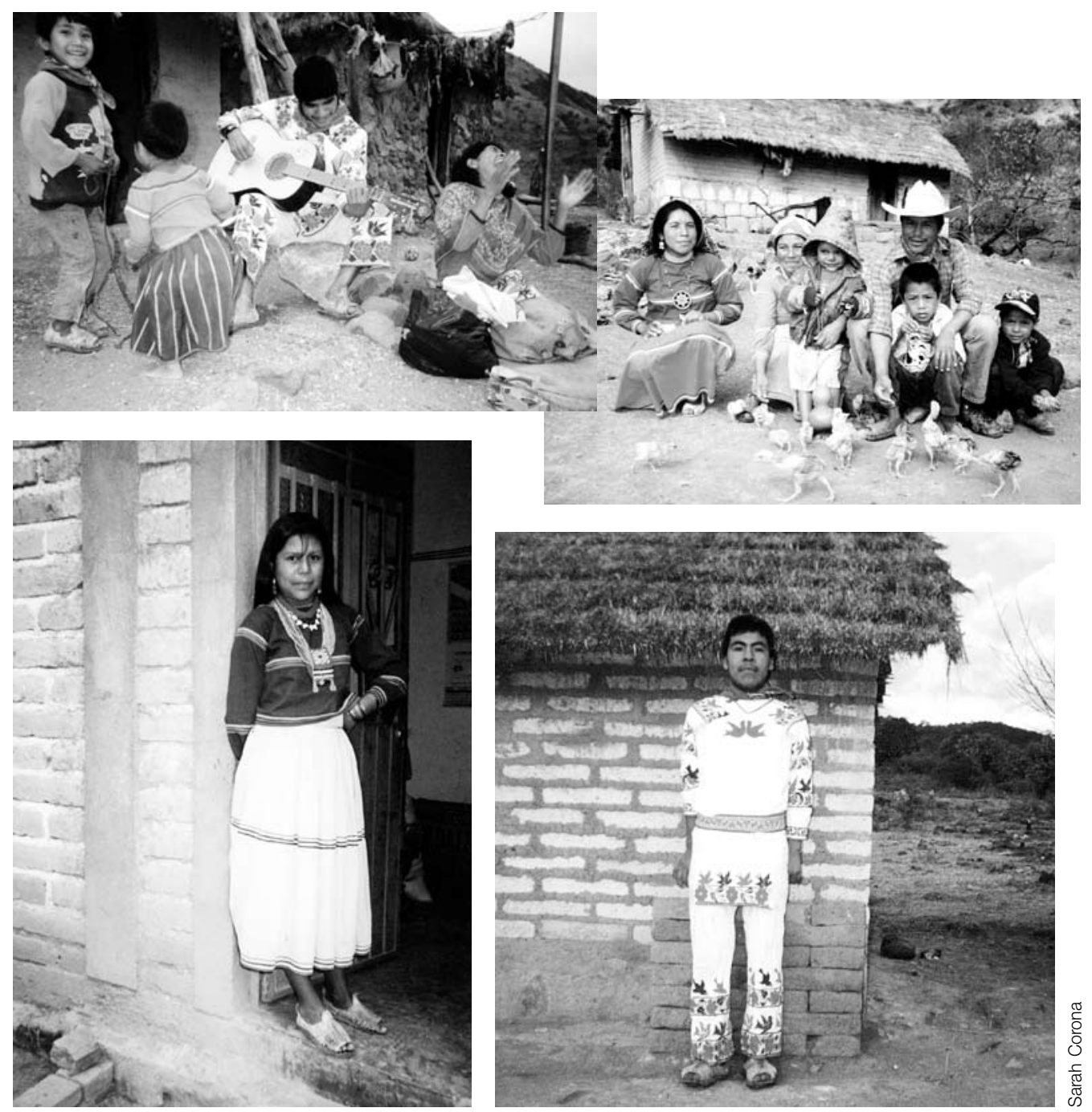

Uso de metodologia combinatória e explicação contextual possibilitou a compreensão da produção de significação da fotografia na comunidade de jovens huicholes.

Num primeiro momento, classificou-se o total das fotografias pelos temas propostos pelos jovens. Por tema entendemos o conteúdo da representação visual - sem entrarmos nesse controvertido campo de discussão, delimitamos os temas a partir de um critério referencial, ou seja, de nosso modelo de objetos, pessoas ou fatos representados, e a partir dos referenciais do fotógrafo, ou seja, 
daquilo que os jovens huicholes expressaram por escrito. Dessa maneira, buscamos relacionar as fotografias com os valores da própria etnia huichola.

Identificamos cinco grandes temas ao redor dos quais se agrupam as fotografias tiradas pelos alunos: Pessoas (em pose e em ação) 64\%; Natureza 21,9\%; Animais 4,9\%; Coisas 3,8\%, e Lugares sagrados 1,1\%. Identificamos também alguns conjuntos que denominamos Séries (narrativas), que completaram 2,4\%, e Erros técnicos (fotos falhadas) 1,4\%. Dada a amplitude do corpus, nesta exposição faremos menção apenas à análise realizada com as fotografias relativas ao tema Pessoas.

\section{A SUPEREXPOSIÇÃO AO VISÍVEL E A DIMINUIÇÃO DOS ESTÍMULOS TÁTEIS}

Nos processos educativos, por se disciplinar o corpo a não tocar, os estímulos à satisfação tátil diminuem. Dezenas de vezes por dia adultos ensinam a criança a não tocar: não pegue porque quebra, porque é perigoso, porque está sujo, porque não se faz. Não toque na rua, no museu, na casa, na loja. O mundo se mostra em vitrines, em fotos, nas telas. Em oposição a essa organização social do tato, está o huichol que toca tudo: senta-se e dorme sobre a terra que é nossa mãe, confecciona sua roupa, seus colares e seus alforjes, prepara o fogo com lenha e sua comida com o que plantou e colheu. As crianças huicholes são poucas vezes repreendidas por tocar facões e facas afiadas ou botar agulhas na boca. Tocar e experimentar lhes ensina o perigoso, o doloroso, o desagradável, mas também o suave, o macio, o prazeroso.

Acompanhei, certa vez, uma família huichol em um passeio ao jardim zoológico de Guadalajara que, maravilhada diante do espetáculo de um pavão real, sentiu-se afastada dele pelo obstáculo das cercas e alambrados que impedem o visitante de se aproximar, acariciar ou simplesmente de escolher um ângulo melhor para observar o animal. Pati, uma jovem huichol, tomou uma pedrinha e, ante o assombro dos visitantes de domingo ali reunidos, atirou-a exatamente aos pés da ave que, em resposta, rodou à nossa frente inclinando majestosamente sua plumagem. Para Pati, atirar a pedra significava estender seu sentido do tato.

Da mesma forma, na linguagem fotográfica, os close-ups são formas de aproximação e toque. Para os ocidentais, que nunca tocam, o close-up é valorizado; enquanto para os huicholes, que a tudo tocam, o mesmo não ocorre. Foi o que nos mostrou o conjunto de fotografias de pessoas que analisamos, revelando um manejo especial do espaço e do corpo humano por inteiro dentro das margens da fotografia. Na sua maioria, são tomadas em plano geral, característica já identificada por outros pesquisadores como própria da estética indígena, e também observada em experiências cinematográficas realizadas com índios navajos. No conjunto analisado, o close-up é quase inexistente e os que encontramos, em apenas duas imagens, provavelmente tinham por 
objetivo não retratar o rosto da jovem, mas os brincos que usava. Isso porque os indígenas utilizam o close-up com maestria para exibir detalhes num conjunto relevante de objetos, composições significantes ou na particularidade de certos processos, como a preparação de um medicamento ou a elaboração de alimentos, por exemplo.

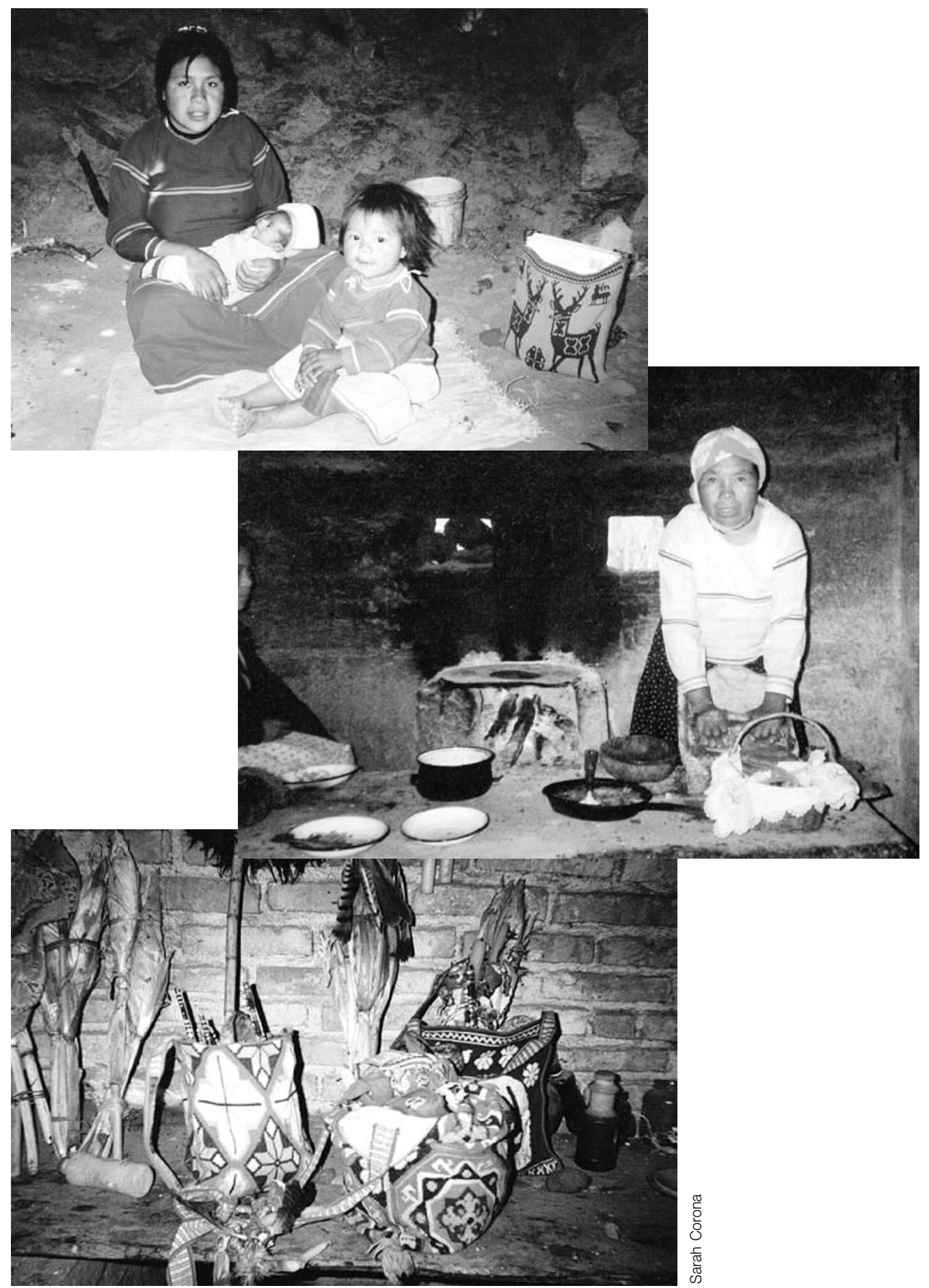

Apenas composições expressivas e processos particulares merecem destaque na estética indígena huichole. 
As tomadas gerais nas fotografias têm a virtude de mostrar claramente o contexto. Pessoas em pose ou em ação, retratadas no seu entorno. O fotógrafo se acomoda à esquerda ou à direita para captar uma imagem completa. Para fotografar a imagem de pessoas diante da sua casa, ele vai além do muro de adobe ou pedra para poder incluir o campo ao fundo; inclina a câmera para cima para integrar as montanhas; arruma a colocação das pessoas no vértice da interseção de dois muros ou, se for o caso, da trama de arame para captar ambos os lados da paisagem. Se estiver dentro de uma casa, abre-se a janela para olhar o exterior; se está fora, abre-se a porta para ver o interior dela.

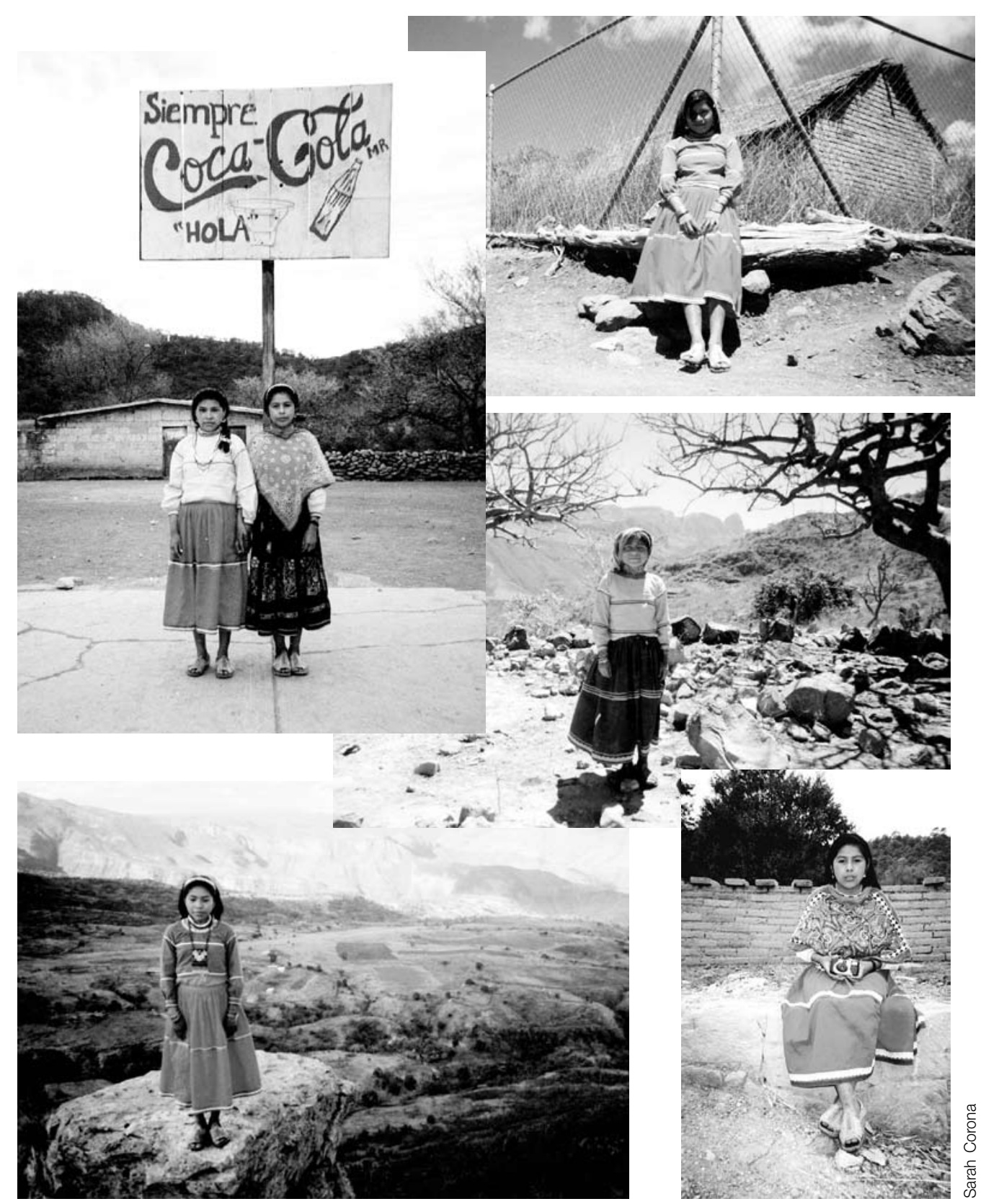

Na sua maioria, as fotografias da experiência foram tiradas em plano geral, característica própria da estética indígena. Nelas, privilegia-se o "ver mundos completos" no lugar de "sentir impressões subjetivas". 
Encontramos dois tipos de fotografias de pessoas: em pose e em ação. As fotografias de pose repetem a tomada de frente: braços ao longo do corpo, gesto sério ou leve sorriso - uma atitude formal diante da câmara, sem o sorriso que Edgar Morin considera como uma das chaves da fotografia nas nossas culturas modernas. "Sorria... Ponha sua alma na janela do rosto", expressa uma característica anímica e sentimental que resulta no manejo do rosto na cultura ocidental da imagem.

As pessoas posam em pé ou sentadas sobre pedras ou sobre a terra. Numa única foto aparece uma criança abraçando o pescoço de outra, com um braço no alto demonstrando força. Não é por acaso que esta única imagem seja de um menino mestiço, o único que mora na comunidade, aos cuidados do pai, um pedreiro da costa nayarita.

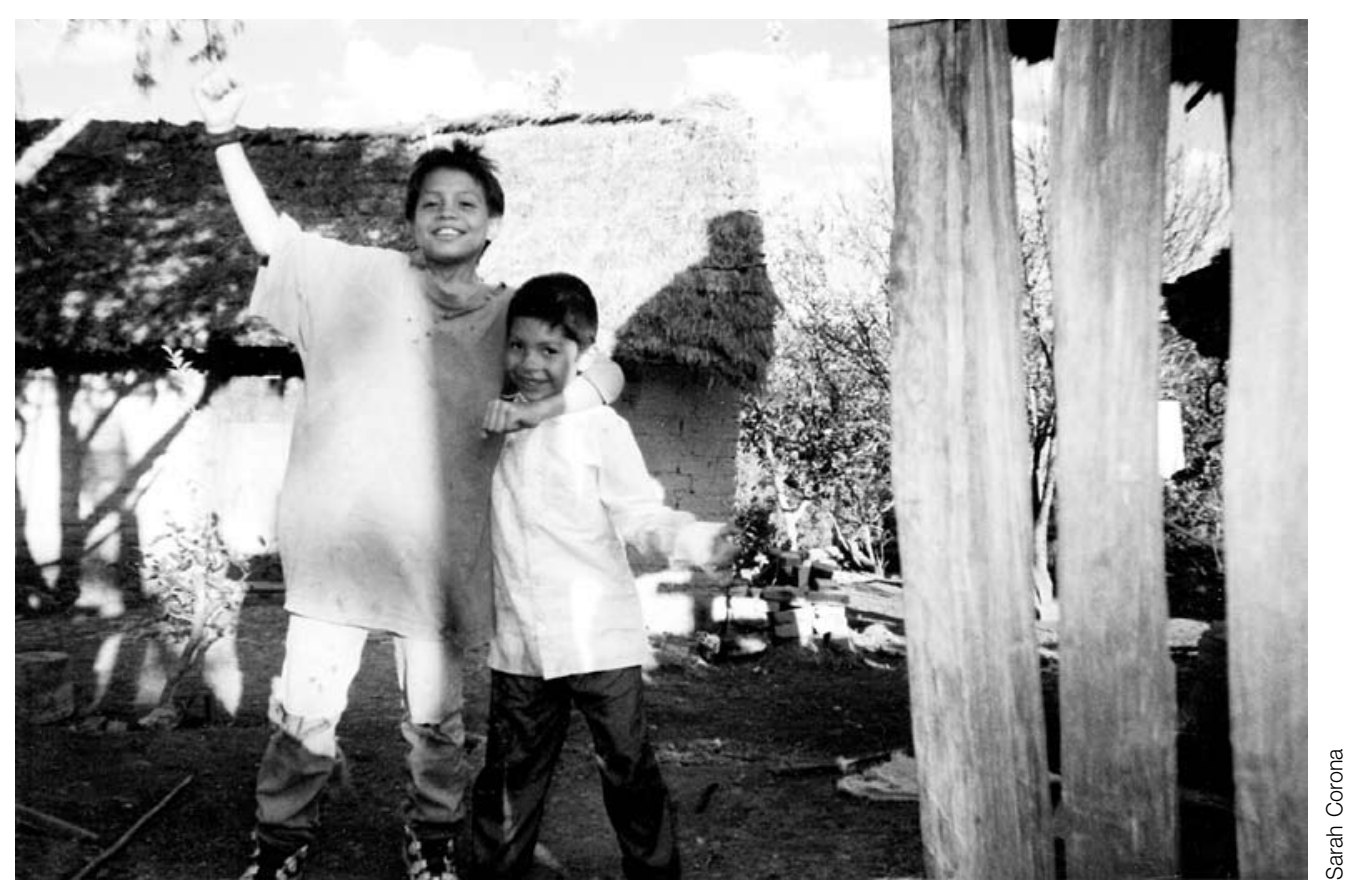

Uma exceção no padrão de fotografias huicholes.

O olhar é sempre dirigido à câmera. Observamos algumas exceções nas poses em que os homens usam roupas de mestiços e metem as mãos nos bolsos das calças ou da jaqueta ou, ainda, quando jovens fazem fila para posar de óculos escuros e com as mãos à cintura, ou com refrigerantes em atitude brincalhona, fingindo estar bebendo.

Ver expressões faciais em sujeitos que possuem a cultura do tocar nos confronta com a tirania ocidental de tocar com os olhos. A TV, o cinema, os cartazes, as etiquetas, a profusa ilustração dos impressos enchem e fartam os olhos. A imagem mediática nos obstrui a capacidade de ser testemunhas da realidade tangível em benefício de substitutos técnicos, os quais nos acercam ao espetáculo do mundo.

Qual o paradoxo? Cegueira por superexposição do visível.

3. MORIN, Edgar. El cine - el hombre imaginario (O cinema ou o homem imaginário). Barcelona: Seix Barral, 1972. p. 43. 


\section{A PERSPECTIVA DA TELA}

A cultura ocidental, segundo os historiadores da arte, interessou-se pela perspectiva por uma questão espacial e não de estilo. Detivemos nossa atenção no espaço, na sua identidade própria e sua percepção. Para Paul Virilio, o horizonte é fundamental na visão do homem. A mudança de percepção está ligada ao conceito que se tem de horizonte.

Historicamente a dicotomia acima/abaixo está relacionada à força da gravidade; mas a perspectiva do Quatrocento acrescenta certa ilusão óptica a esse parâmetro. A ilusão ótica atual, que surge com a TV e a velocidade da luz, ainda está por ser explorada e analisada. Esta nova perspectiva, sem horizonte, de primeiro plano (pergunta-se Virilio), ao perder profundidade de campo, causará empobrecimento na nossa visão?

A antiga perspectiva, a partir do século XI, que distingue o zênite do nadir, é determinada pelo nosso peso e orientada pela gravidade terrestre; a referência visual está diretamente relacionada à nossa atração à Terra. Não há profundidade de campo: acima estão damas ou anjos, abaixo cavaleiros montados nos seus cavalos e o observador cara a cara com as figuras e ao mesmo nível das damas e cavaleiros. A pintura não está relacionada com o ponto de vista do observador.

A partir do século $\mathrm{XV}$, populariza-se em toda a Europa a perspectiva como forma de relacionar o observador com a obra artística. Assim, a distância entre quem olha e os elementos espaciais do quadro está claramente definida. Em alguns casos, os objetos, as telas, os corpos convidam a ser tocados, impressão criada porque o espectador compartilha do mesmo espaço que observa.

Qual é a percepção espacial nos huicholes e qual a dos ocidentais imersos na cultura da imagem mediática?

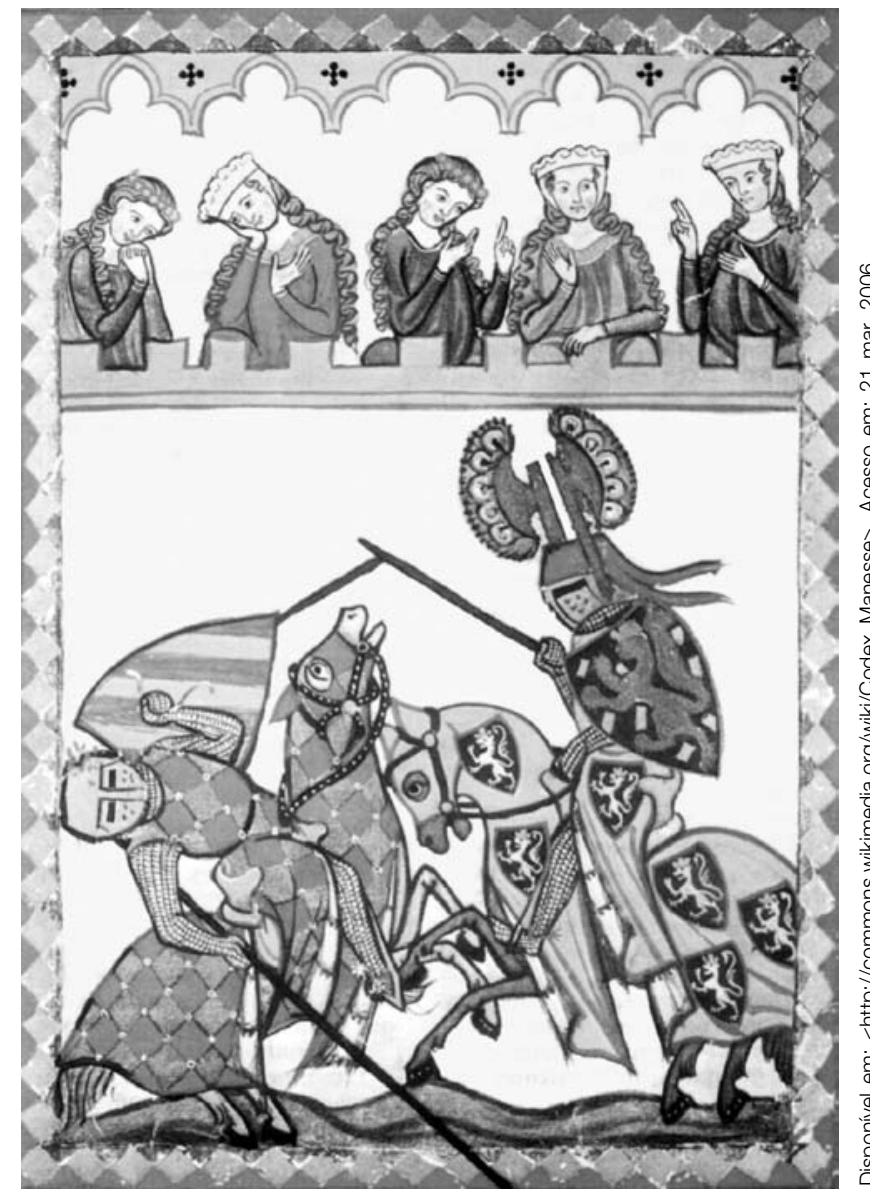

Uma das figuras do Codex Manese (Grande Livro de Canções de Manesse), livro copiado e ilustrado entre 1305 e 1340 em Zürich, presumivelmente compilado por Johannes Hadlaub. Contém canções de amor de poetas alemães importantes da Alta Idade Média. 
Os cenários são principalmente exteriores. Temos observado através de outras experiências a importância que se dá ao entorno e ao fundo, e a menor concentração que se evidencia no primeiro plano. No conjunto de fotos que apresentei durante as entrevistas, os jovens não hesitaram em formular opiniões do tipo: "não sei onde está", "não entendo o que está fazendo", "não sei bem o que quer dizer".

Também fui surpreendida, em outras ocasiões, com crianças e mestres que me fizeram ver o fundo de certas fotografias jornalísticas que eu não tinha observado. Alejandrina, aluna do terceiro ano primário, durante um exercício que consistia em fazer a nota de rodapé de uma fotografia do jornal escolhido por ela, escreveu sob uma foto da banda de rock Rolling Stones: "são lindas as flores". Ante meu assombro, a menina mostrou-me que gostava das flores vermelhas, que, aliás, se encontravam num pequeno prado, quase imperceptível para mim, como fundo da fotografia dos músicos.

Os corpos fotografados têm a característica de aparecer sempre completos, não se fazem tomadas de meio-corpo, nem close-ups. Para os huicholes, que não conhecem o close-up constante da televisão, do cinema ou da publicidade, o que significaria um corpo desmembrado?

Nos seus artesanatos de chaquira, bordado e quadros de lã, as figuras estão sempre completas, salvo nos casos em que se representam os rostos dos deuses. "O veado se vê assim primeiro, com o peyote (planta), só a sua cara”, diz-me Daniel Castro, sobre um dos seus quadros de lã. Talvez o nierika $a^{4}$ permita ao homem se acercar dos deuses cara a cara, e por isso só os deuses aparecem sem corpo e nunca os homens que, certamente, sempre se comunicam de corpo inteiro.

Para Edgar Morin, a era do close-up, que privilegia o rosto humano, transformou a civilização. O rosto adquire uma dignidade única, suprema, onde todos os dramas se focalizam e toda a ação sucede. Qual é o efeito disso? A hipertrofia, a complacência, o aumento anormal da satisfação dos sentimentos, que, com o exagero, se inflam anormalmente e endurecem. Dito de outro modo, assinala Morin, "a alma se destrói ao querer colocar-se como realidade autônoma [...] perde a comunicação com os canais alimentadores do universo" ${ }^{5}$. Ante o esteticismo, o manejo dos estados de ânimo nos rostos, na natureza, nas tomadas e seus ângulos, nas cores, enfim, na exaltação dos sentimentos como características da cultura das imagens, as fotos dos huicholes mostram descrições minuciosas e múltiplos detalhes; nas suas fotografias de plano geral, de poses austeras, privilegia-se o ver mundos completos no lugar de sentir impressões subjetivas.

Uma nova organização do olhar se perfila com as novas tecnologias visuais. O acima/abaixo relacionado com a gravidade tem sido desafiado pela possibilidade de cair para cima. A missão do Apolo 11, os buracos na camada de ozônio, a comunicação via satélite, transformam nosso olhar: "nosso céu se esfuma", diz Virilio.

O horizonte toscano da perspectiva italiana, que permitia olhar o mundo pela janela, cede lugar ao espaço extraterrestre, do cosmo sem horizonte. Suprimimos assim, de passagem, nosso conhecimento das distâncias e dimensões.
4. Para os xamãs huicholes existe uma porta dentro de nossas mentes que normalmente permanece oculta e secreta até o momento de morrer. A designação huichol para ela é nierika, um acesso ou superfície de contato cósmico entre as chamadas realidades ordinária e não ordinária. Disponível em <http://www.terramistica. com.br>. Acesso em: 11 mar. 2006. [N.E.]

5. MORIN, Edgar. El cine o el hombre imaginário... Op. cit., p. 126

6. VIRILIO, Paul. Open sky (Céu aberto). Londres: Verso, 1997. p. 2. 


\section{DESCONTEXTUALIZAÇÃO}

O pensamento descontextualizado é próprio do homem, que pode estar em todas as partes sem se mover do lugar, em que sua experiência dos espaços não corresponde ao deslocamento do seu corpo. Na era da imagem mediática, o contexto desaparece na indeterminação e aparecem no seu lugar, como rajadas de metralhadora, os fragmentos de dados descontínuos. Idriss, o personagem berbere de Michel Tournier, responde ao companheiro francês: "os franceses sempre têm que explicar tudo"7. Esta observação feita por um personagem fundamentalmente oral nos faz pensar na comunicação no Ocidente, onde, na falta do contexto, é preciso preencher os espaços com infinitas explicações. Evans-Pritchard ${ }^{8}$, em uma pesquisa com os nuer recolhe a frase: um pepino é um boi. Isto, comenta, não é exemplo de um pensamento pré-lógico, mas de um pensamento contextualizado. Para os que sabem, para a comunidade que intercambia idéias contextualizadas, um pepino é equivalente a um boi comparado com Deus, que o aceita em lugar de um boi.

A contextualização permite fazer mais conexões com outras unidades do pensamento. Assim, nas fotos huicholes, identificamos contextos completos e não dados isolados que requerem explicação para ser compreendidos.

$\mathrm{Na}$ fotografia huichol achamos que o contexto geográfico, sua atividade econômica e sua forma de comunicação, principalmente oral, se inter-relacionam para produzir mensagens em imagens. Os huicholes de San Miguel Huaixtita vivem a 2.200 metros de altura, no cimo da Sierra Madre Ocidental. O desenho de Osvaldo, de oito anos, me permitiu constatar que o símbolo infantil de montanha que conhecemos é uma convenção social. Seu desenho mostrava raias retas, paralelas horizontais na parte superior da página, que ele identificou como montanhas. Efetivamente, as montanhas da Sierra Madre Ocidental parecem diferentes vistas do alto; igualmente, o nascimento e o pôr do sol, os caminhos e as distâncias disciplinam de forma diferente o olhar.

7. TOURNIER Michel. La gota de oro (A gota de ouro). Madrid: Alfaguara, 1988. p. 155.

8. EVANS-PRITCHARD, E. E. In: DENNY, J. Peter. El pensamiento racional en la cultura oral $y$ la descontextualización escrita $(O$ pensamento racional na cultura oral e a descontextualização escrita), en Cultura Escrita y Oralidade. Barcelona: Gedisa, 1995.

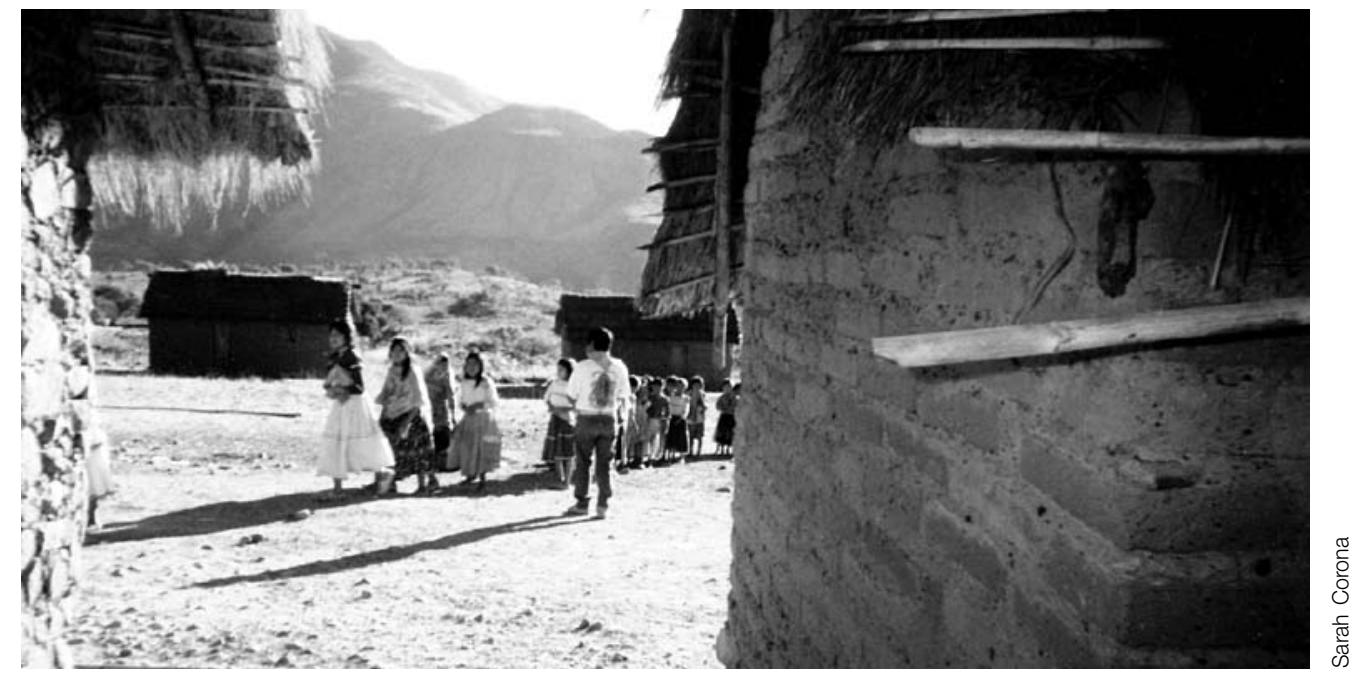

Cenários exteriores, com grande importância para o entorno e o fundo. As montanhas da Sierra Madre Ocidental ao fundo não aparecem de forma casual ou acidental. 
Também encontramos, nas fotografias huichol, a influência de seu conceito de pontos cardeais. Para os huicholes existem cinco direções: o norte, o sul, o leste, o oeste e o centro, que compreende acima e abaixo. Cada direção ou região está povoada por deuses que são sempre mencionados - e convidados às festas, a comer, caçar, bordar -, assim como aparecem em manifestações aparentemente insignificantes.

A influência dessa forma de se orientar geograficamente em cinco direções, e não em quatro, se manifesta desde a infância. Num jogo ocidental amplamente conhecido como Jogo da Oca, tive dificuldade para explicar a um grupo de crianças huicholes como avançar pelo tabuleiro. Mesmo que não mostrassem dificuldade em contar os espaços ou as marcas dos dados, perdiam pontos, em cada jogada, ao começar a contagem a partir do espaço onde se achava sua ficha. Confundiam-se com a regra, que manda saltar o próprio lugar da ficha e iniciar a contagem pelo espaço seguinte. O problema foi finalmente resolvido por Erly, de cinco anos, que propôs chamar de 0 (zero) o lugar no qual se achava sua ficha e do qual partia. Dessa maneira, nomeando o lugar próprio, a quinta direção, não houve mais problema para avançar.

O lugar onde se coloca o fotógrafo incide fundamentalmente na composição da fotografia. O centro do fotógrafo huichol não é o que geralmente se espera da foto de um amador: de frente para a pessoa ou objeto fotografado. No corpus de fotos analisadas, percebemos que a câmera se acomoda para que as pessoas ou animais se integrem à paisagem. Desse modo, o todo tem mais peso que a pessoa em pose, que pode estar à esquerda ou à direita para não cobrir uma casa, uma montanha, ou mesmo uma pedra, que é parte do conjunto. Parece que, à maneira oral da comunicação, em que o signo não se separa de sua origem, e diferentemente do mundo da escritura e das mensagens eletrônicas, nas quais a comunicação, separada de sua fonte física, voa por espaços e tempos, a fotografia huichol reproduz uma percepção da qual o corpo e o olho participam.

Estudar dessa maneira o sujeito implica a necessidade de se distanciar da tendência dos estudos que contemplam o pólo da recepção e suas múltiplas determinações. Estudar receptores permite conhecer parcialmente a significação que grupos diferentes atribuem à tecnologia comunicativa; não obstante, se partirmos do fato de que os meios são uma das tantas instâncias, um dos tantos objetos com os quais o sujeito se relaciona de forma complexa, é necessário deslocar o olhar dos meios para os sujeitos, daquilo que segmentos da sociedade fazem com a produção mediática, para a produção comunicativa dos atores sociais. Tentar se distanciar do mediacentrismo de forma radical, ou seja, partir dos huicholes, sujeitos em contextos culturais, despojados dos meios massivos de comunicação, que não podem, portanto, ser considerados receptores mediáticos, oferece a possibilidade de estudar o sujeito comunicacional com base no discurso que o propõe e o impõe como sujeito da enunciação.

Assim, ante os modelos, abarcadores por definição, e à procura das regularidades, estudar o sujeito supõe interessar-se pela produção de sentidos múl- 
tiplos, pelas diferenças e exceções. Estudar as mulheres e os homens, na vida diária, o sujeito produtor-receptor, receptor-produtor de múltiplas significações, não requer modelos cada vez mais amplos e exatos de abordagem. Estes, ao suplantar o "real pelos signos do real, ou seja, uma operação de dissuasão de todo o processo real pelo seu duplo operativo", perdem o sentido do acontecimento e se distanciam da compreensão do sujeito.

Ainda que a ausência de modelos para a pesquisa do sujeito provoque inquietação e problemas, por não oferecer a ilusão do todo-controlável e todoexplicável, e por colocar em jogo disciplinas como a semiótica, a antropologia, a sociologia e a psicologia, por outro lado, pode nos acercar ao sujeito, através dos discursos que produz. E para nos acercarmos dos processos de subjetivação, mediante os quais se adquirem as competências comunicativas, não como impacto ideológico, mas vistas como ativa e tecnicamente inscritas no corpo mesmo do sujeito.

Resumo: A autora relata e analisa experimento realizado com os huicholes, grupo indígena do México, tradicional e de forte oralidade, por meio da fotografia. Distribuindo máquinas entre estudantes e professores, analisou 2.700 fotos captadas da comunidade e organizadas por temas. A partir de um esforço interpretativo e de entrevistas nas quais os próprios jovens relatavam o que viam, pôde estabelecer comparações entre as formas de conceber figura e fundo, de compor a imagem e de posicionar a câmera entre esse povo não submetido aos meios de comunicação e os ocidentais, condicionados à videocultura ou à hegemonia da imagem eletrônica. Por sua metodologia de pesquisa, centrada no enunciador, ela propõe modelos explicativos menos abrangentes e mediacentrados.

Palavras-chave: fotografia, cultura, oralidade, videocultura, imagem e comunicação.
Abstract: The author relates and analyzes an experiment with the use of photography among the Huichole people, Mexican Indian group, traditional and of strong orality. Cameras were distributed among students and teachers, who took 2.700 pictures from community which were organized by themes and analyzed. By doing an interpretative effort and interviews in which the youngsters told what they saw, she could set comparisons between the ways of conceiving figure and background, of composing image and positioning the camera by this people not submitted to media and Occidentals, not conditioned to the video culture or the hegemony of electronic image. By her research methodology, centered in enunciator, the author proposes explicative models less comprehensive and media centered.

Keywords: photography, culture, orality, video culture, image, communication. 